\title{
PARTICIPATION IN PUBLIC CONSULTATIONS ON SPATIAL PLANNING DOCUMENTS. THE CASE OF POZNAŃ CITY*
}

\author{
Tomasz KaczMareK, Michą Wójcicki \\ Institute of Socio-Economic Geography and Spatial Development, \\ Adam Mickiewicz University in Poznań, Poland \\ Manuscript received: December 1, 2015 \\ Revised version: January 31, 2016
}

\begin{abstract}
KaczmareK T., Wójcicki M., 2016. Participation in social consultations on physical planning documents. The case of Poznań City. Quaestiones Geographicae 35(2), Bogucki Wydawnictwo Naukowe, Poznań, pp. 71-81, 7 figs.

ABSTRACT: This article seeks to present the development od public participation in local spatial planning in Poland. An assessment was made of the procedure of preparing planning documents and forms of their consultation with residents. To achieve this goal, use was made of the results of a survey research conducted among participants of public consultations in Poznan in the years 2012-2014. It is stressed that it is necessary to improve the decision-making process in urban spatial planning by accommodating not only traditional but also new forms and instruments of public participation.
\end{abstract}

KEY WORDS: spatial planning, public consultations, consultation participants, Poznań

Tomasz Kaczmarek, Michał Wójcicki, Institute of Socio-Economic Geography and Spatial Management, Adam Mickiewicz University, ul. Dzięgielowa 27, 61-680 Poznań, Poland; e-mail: tomkac@amu.edu.pl, micwoj@amu.edu.pl

\section{Introduction}

As Izdebski (2010) observes, today public management does not belong exclusively to a public authority. This is due to a departure from treating citizens only as voters, volunteers or consumers of public services and a transition to seeing them as stakeholders and - by giving them their own problems to solve - co-decision-makers and co-creators of the common good. For a few years now a new approach to management can be observed in Polish towns, especially big ones, which accommodates elements of 'the right to the city' that Harvey (2012) describes as the possibility for residents to decide about what is happening in their town and in what direction it develops.

Participation in the management process can be passive or active (Ziemkiewicz 1990). Passive participation means a right to information, a right to lodge complaints and express opinions, and a right to give counsel. Active participation means a right of individuals to express an objection or consent, a guarantee of taking part in settling specified public matters or doing it on their own. Thus, participation involves four basic elements: (1) giving information, (2) obtaining information, (3) interactions: consultations, and (4) exerting an influence: co-deciding.

* The research described in this paper was supported by the project An Experimental Study of Public Participation in Planning Decision-Making Using Web-based Geographic Information Systems, funded by the National Science Centre in Poland; funding decision DEC-2012/05/B/HS4/03850. 
An active involvement of society in the decision process appears only at the stage of public consultations. It is then that interaction between process initiators and its participants actually takes place. Consultations usually take the form of direct meetings, public discussions, workshops, or public-opinion hearings. However, a public consultation on decisions by authority or administration organs need not mean negotiating, and even less deciding matters. Consultations are a way of obtaining opinions, standpoints, proposals, etc. from entities (institutions or persons) that will somehow be affected (directly or indirectly) by the effects of ventures proposed by administration (Wygański and Długosz 2005).

New forms of participation of residents and their representatives, not only those guaranteed statutorily, are also being introduced into the decision process in spatial planning. Space is a common good, so everybody should have equal access to it and a say in its formation in the nearest vicinity. In the Spatial Planning and Spatial Development Act of 27 March 2003, the basic principle of planning activity is sustainable development. One of its goals, as stated in the Environmental Protection Act of 27 April 2001, is ensuring individual communities and individual citizens the satisfaction of basic needs. It follows from this principle that spatial planning should accommodate the needs and interests of residents.

This article seeks to present the level of public participation in local spatial planning process in Poland. An assessment is made of the procedure of creating planning documents and forms of their consultation with residents. To achieve this goal, use was made of the results of a survey research conducted among public consultation participants in Poznań in the years 2012-2014. The survey, one of the main objectives of which was to identify the socio-demographic characteristics of participants of the public consultation, was conducted during 26 meetings in the process of preparing Local Development Plans in Poznań. It was possible to identify the participants in terms of their reasons for participating in consultations, their level of knowledge in the field of spatial planning, and such variables as sex, age, education, and occupational structure. The sample was directly dependent on attendance in a consultation and embraced 382 persons. This represented $62 \%$ of the 558 people present at all the 26 public consultations. It was found that the decision process in urban spatial planning could be improved if traditional forms and instruments of public participation were augmented with new ones. The article also presents the results of an experiment where innovative public participation tools in the spatial planning process based on GIS were used.

\section{Statutory forms of participation in the spatial planning process}

Spatial planning, both in Poland and most European states, is one of the basic tasks of self-government units. Modern city planning must take into account several phenomena occurring in social, political and economic space. The evolving ideas of direct democracy and citizen participation, and a growing social awareness concerning living conditions and the role of an individual in public life, are only the most important factors underlying participatory spatial planning.

Among the basic factors affecting the operation of public administration and its tasks are legal regulations in force. They provide, as Izdebski (2011) observes, the basic reference frame for all measures taken by public administration, thus directly influencing its performance and efficiency. Legal stipulations provide a foundation for the operation of local governments and other participants of the planning process. A greater share of local communities in the preparation of planning documents was guaranteed by the Spatial Planning and Spatial Development Act of 2003 (SPaSDA). It obliges all local governments in the country to proceed in spatial planning matters in accordance with the principles in force, on pain of the invalidity of some or all administrative procedures. The Act lists principles and instruments that local communities and other interested parties can use to join in the planning process.

As Mergler et al. (2013) observe, in the early period of the systemic transformation the Spatial Planning and Spatial Development Act of 1994 and the one of 2003 currently in force introduced a change in the approach towards the development of space from a command (redistributive) system to one giving communes planning autonomy. The commune obtained planning power, or 
the power to decide on its own about the way it developed its territory, being controlled only for a correct implementation of procedures and not the rationalism and content of the plans worked out.

The forms of public participation in preparing studies of the conditions and directions of spatial development and local spatial development plans follow from concrete provisions of the 2003 Act which allow interested parties to:

1. submit proposals for a study (art. 11 section 1 of the SPaSDA) and for a spatial development plan (art. 17 section 1 of the SPaSDA);

2. take part in a public discussion of solutions adopted in the draft of a study (art. 11 section 10 of the SPaSDA) and the draft of a local plan (art. 17 section 10 of the SPaSDA); and

3. submit comments on the draft of a study (art. 11 section 11 of the SPaSDA) and the draft of a local plan (art. 17 section 11 of the SPaSDA).

The first, and basic, element connected with public participation in local development plan preparation is informing society about the local government's resolution to start this process. The information can be disseminated in three ways:

1. by an announcement in the local press,

2. by a public notice, or

3. in a way customary for a given locality.

The extension of information channels is the most efficient way of reaching as great a number of interested persons and institutions as possible. Apart from the justification of the start of work on plan preparation, the resolution also contains information about the possibility of submitting proposals to the plan by interested parties. The time for this cannot be shorter than 21 days. In accordance with art. 17 section 4 of the Spatial Planning and Spatial Development Act, all proposals collected during this time must be considered by the plan-making organ (a city's president, a town's mayor, or head of a Commune Council). However, the executive organ is not obliged to accommodate them in the draft of the plan.

From the point of view of public participation in the planning process, a key stage is making the draft of a local plan available for public inspection and arranging a public discussion of the solutions adopted in it. The draft-preparing organ is obliged to publish, at least 7 days before the presentation date, an announcement with information about the time and place of presentation and the public discussion. The minimum period of access of all interested parties to the draft plan is 21 days. During the time the document is presented for public inspection a public discussion is arranged that can be attended by anyone interested in the given matter with no limitations. The last stage when social involvement in the procedure of local plan preparation is guaranteed by the Spatial Planning and Spatial Development Act is the submission of comments to the draft plan. To fulfil procedural requirements, when the public presentation has finished, the draft-making organ collects formal comments from interested parties.

In accordance with art. 18 of the Spatial Planning and Spatial Development Act, comments can be submitted by anyone who questions provisions adopted in a draft plan intended to be presented publicly. The maximum time for their submission by all interested persons or institutions is 14 days from the date when the presentation of the plan for public inspection ends. A comment to the draft plan, like a proposal submitted at an earlier stage of the procedure, must be considered by the president, mayor or commune head not later than 21 days since its submission. However, as in the case of proposals, comments need not be accommodated in the draft plan being prepared. A list of comments disregarded in the further procedure is passed on to the Commune Council together with the final draft of the plan for its opinion and approval.

This lack of any impact of proposals and comments on spatial decisions shows participation to be practically fictitious, as pointed out, e.g., by Billert (2006), Jędraszko (2008) and Parysek (2010). The statutory instruments of public participation, especially proposals for and comments to draft plans, are only treated as a requirement for the procedural correctness of the process. The Act creates a situation in which, first, those instruments do not ensure any influence on the draft plan, and secondly, and more importantly, it makes it possible to ignore opinions completely with no justification offered.

This situation is open to many dangers. As Goździewicz-Biechońska (2008) and Arnstein (2011) observe, the inability of a local community to influence planning decisions can result in giving more freedom to local authorities and other influential interest groups, e.g. property owners, 
developers, designing firms, or influential groups of residents.

Given the statutory regulations concerning public participation in spatial planning, its public control and active involvement of society are clearly unsatisfactory. There are no precise rules as to how proposals and comments to plans and studies can be accommodated by a public authority organ, and the legal position of a public discussion in the planning process is highly unclear. In accordance with the Spatial Planning and Spatial Development Act of 2003, a protocol from a public discussion conducted is only an attachment to the obligatory documentation of the administrative process, and its conclusions are in no way binding for the organ preparing the plan or study. Unlike the proposals and comments submitted, the results of a public discussion do not even undergo examination. This highly significant participation instrument can therefore be regarded as completely inefficient. As noted by Jaroszyński and Sawicki (2004), Hanzl (2008) and Parysek (2010), the legal regulations of public participation in spatial planning currently in force are far from what this process should in fact be.

Thus, the statutory regulations concerning the share of residents in preparing local spatial development plans and studies of the conditions and directions of spatial development can be treated as falling short of expectations and not ensuring local communities enough say in co-deciding about the contents of those planning documents. The following are legal weaknesses of the present spatial planning system in Poland (cf. also Hanzl 2008):

- no statutory possibility of the involvement of a community in the preparation of assumptions to draft plans and studies,

- social involvement in the planning process being reduced only to the submission of proposals and comments and to participation in a public discussion,

- low efficiency of such legal instruments as proposals and comments to draft plans because they can be ignored by the executive organ,

- no definition of a public discussion about the presentation of a plan or study, which allows using all possible methods than can be questioned at a later stage,
- a limited possibility of translating the results of a public discussion into planning decisions, and

- no rules as to publicising draft plans through the media, including the transmission of the public discussion.

It is worth emphasising that the provisions of the Spatial Planning and Spatial Development Act do not preclude in any way an expansion of the existing procedures, e.g. raising the level of participation of the planning process. This leaves room for bottom-up initiatives, as in the example of social involvement in the planning process in Poznań presented below.

\section{Non-statutory public consultations on planning documents: an example of Poznań}

Polish experience in the application of non-statutory forms of public participation in spatial planning is not yet extensive. With legal regulations concerning the involvement of society in spatial planning unsatisfactory and failing to meet social expectations, there appear non-statutory self-government initiatives intended to increase public participation. One can note positive tendencies: local governments seek and gradually implement new, more efficient ways to include an ever wider range of participants in the planning process.

Poznan is one of the forerunners of participatory spatial planning in Poland. It has extended the statutory procedures of public consultations on local plans worked out in the city. There are additional public consultations with residents that are not stipulated in the Planning Act. Nonobligatory public consultations have become a constant element of urban planning practice, being organised on a systematic basis ever since 2007 for each plan prepared in the city.

Non-statutory public consultations on local spatial development plans in Poznań are a supplement to the statutory planning procedure which, as Billert (2006) and Parysek (2010) note, is completely unsatisfactory and does not ensure interested parties a say in the plan being designed because the Spatial Planning and Spatial Development Act guarantees physical participation of residents in its preparation only 
at the public discussion stage. In the consultation model adopted in Poznań, the statutory public discussion is a third stage of consultations on the draft plan. Fig. 1 presents a planning procedure diagram, indicating the stages of statutory and non-statutory public consultations organised by the Poznań City Office.

The first stage of public consultations takes place after the publication of information about the Poznań City Council's resolution to start preparing a local plan. This occurs before the formal date of the submission of plan proposals by interested parties. The first public consultations are conducted in the area covered by the plan being adopted or near it, usually in public places known to a local community, like common rooms, housing-estate classrooms, schools, kindergartens, etc. The unit responsible for organising and moderating meetings is the President's Office, the chief organiser of all public consultations with residents conducted in Poznań on matters important for the city's development. Substantive provisions, in turn, are prepared by representatives of the Municipal Town-Planning Office - planners performing concrete planning work. Also involved in the organisation of meetings are appropriate housing-estate councils; because of their venue, they act as their hosts. The first consultative meeting is primarily informative, with workers of the Municipal Town-Planning Office explaining in detail the goals to be attained by the plan being prepared. In a multimedia type of presentation, they discuss exact boundaries of the area covered by the plan, appropriate provisions of the study of determinants concerning intended land uses, and major spatial problems, potential collisions of functions, or possible social conflicts occurring in the area in question.

During that first consultative meeting neither a draft of a local plan nor any concrete conception of land development are presented. This stage is largely educational and informative in nature. Its participants get acquainted with the procedure of passing local plans in the city, chief notions in the field of spatial planning, and the work of urban units responsible for the implementation of the city's spatial policy. A key element of the first consultative meeting is a discussion during which participants are free to express their opinions, comments or proposals. Its result is often valuable information for planners preparing a local spatial development plan. They learn about expectations of a local community as to the development of spaces closest to their places of residence and about many spatial problems often invisible to persons from outside. At the close of each meeting the organisers encourage all interested participants to submit proposals to the draft plan being prepared.

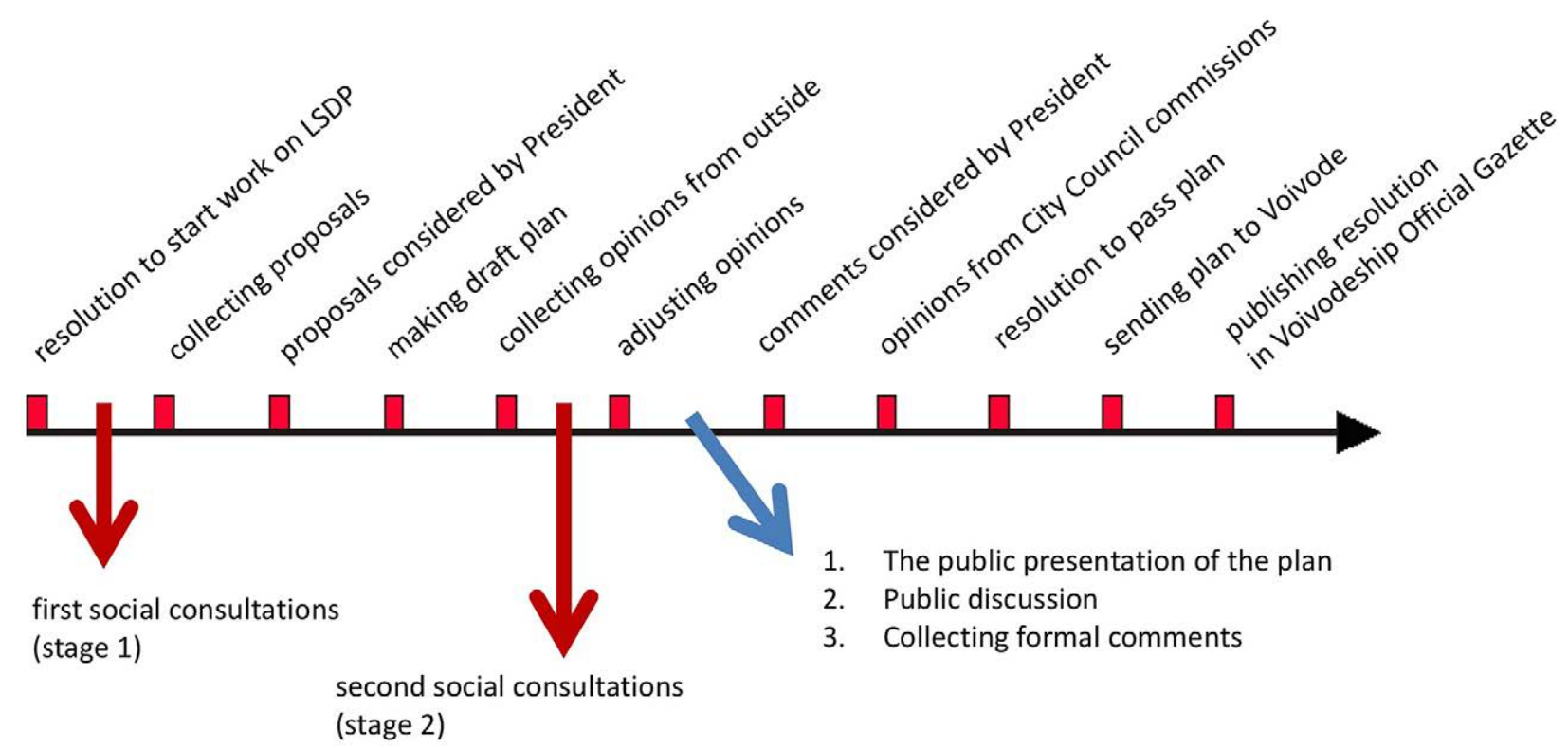

Fig. 1. Preparation of local spatial development plans (LSDP) in Poznań, with stages of statutory and nonstatutory public consultations.

Source: own compilation. 


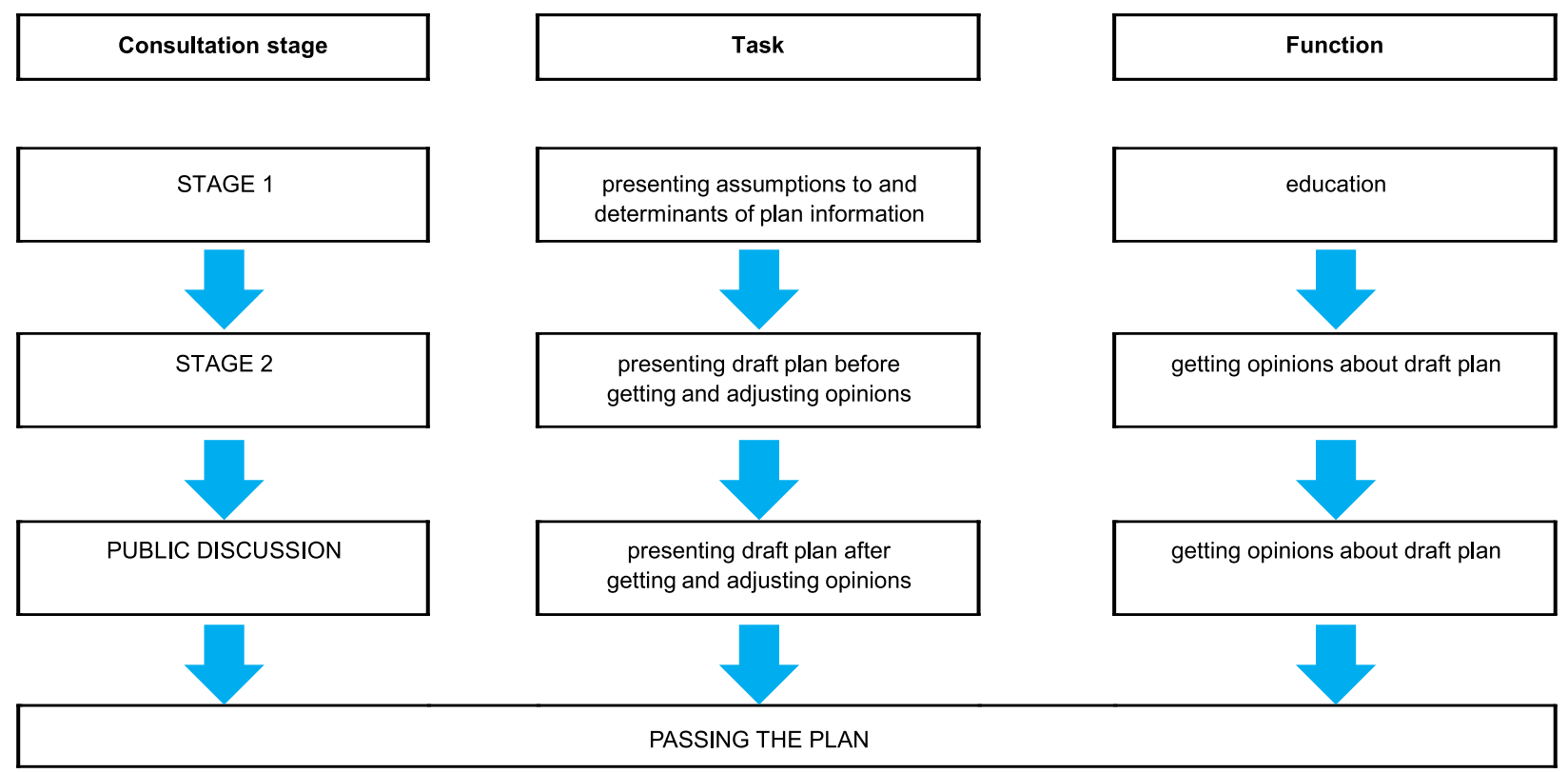

Fig. 2. Tasks and functions of public consultations in the procedure of preparing local spatial development plans in Poznań.

Source: own compilation.

The second stage of non-statutory public consultations when preparing local plans takes place after obtaining inside opinions about the draft and before obtaining and adjusting opinions with outside entities, e.g. with the Urban Planning and Architecture Department. At a meeting held at a site covered by the plan being prepared, the participants are shown the draft of a local spatial development plan for the first time. Planners discuss in detail all the solutions it proposes and the intended uses and functions of the site. As at the first stage, they explain all procedural questions connected with the preparation of planning documents in Poznań. An important element of the meeting is the discussion of its participants about assumptions to the draft plan, moderated by President's Office workers.

In accordance with Poznań President's decision of 2013, the information about the organised consultative meetings has to be published on the city's official website not later than 10 days before the consultation date. It is also placed on the websites of the Municipal Town-Planning Office and housing-estate councils, and announced in the local media. In addition, as part of cooperation with the Poznan City Office, estate councils get posters informing about the date and place of consultations that they should distribute in the area covered by the local spatial development plan. Each consultative meeting, both at the first and second stage, is registered by the President's Office workers, and their audio recordings can be obtained by all interested persons.

The introduction of additional, non-statutory public consultations into the spatial planning system in Poznan is a big organisational challenge requiring the involvement and coordination of efforts of appropriate departments of the Poznan City Office, the Municipal Town-Planning Office, and estate councils.

\section{Chief characteristics of participants of public consultations in Poznań}

People taking part in public consultations on local spatial development plans in Poznań were characterised on the basis of a survey research conducted among 382 participants of 26 consultative meetings between October 2012 and November 2014. One of its goals was to identify them in terms of reasons for participating in consultations, their level of knowledge in the field of spatial planning, and such variables as sex, age, education, and occupational structure.

A considerable majority, as many as $68 \%$, of all those participating in public consultations about local plans are males. In terms of age, 


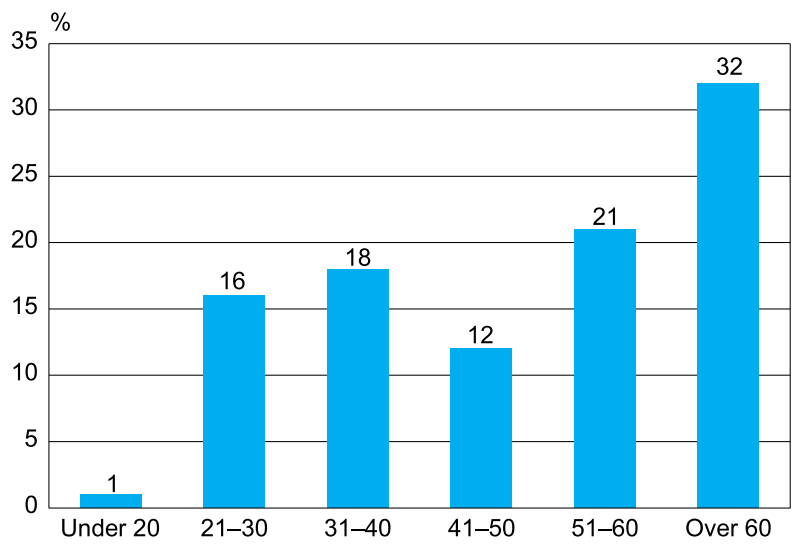

Fig. 3. Structure of consultation participants by age. Source: own compilation.

clearly visible are people over 50 , this group accounting for more than a half $(54 \%)$ of all consultation participants, $32 \%$ being persons over 60 (in the total Poznań population the proportion of inhabitants of this age is half this figure). Young persons, under 20, generally do not take part in public consultations on local plans.

A decided majority of people taking part in public consultations have higher education $(64 \%)$. Nearly $30 \%$ are persons with secondary education, and $7 \%$, with vocational education. As follows from the research conducted, persons with primary and lower secondary education account for a small percentage of meeting participants.

The structure of consultation participants by current occupation shows those most involved and interested in consultations to be: pensioners $(29 \%)$, employees of private firms (19\%), entrepreneurs $(17 \%)$, public administration workers $(12 \%)$, freelancers $(11 \%)$, students $(5 \%)$, non-working people $(4 \%)$, the unemployed $(1 \%)$, and others $(2 \%)$. Among the freelancers there are usually architects and designers as well as physicians and scientific workers.

The most common source of information about public consultations organised by the Poznan City Office is the Internet (32\%), including its own website (10\%), that of the Municipal Town-Planning Office (8\%), and of other institutions (14\%). A significant function is performed by the local Internet service www.epoznan.pl, from which more than $10 \%$ of consultation participants derive information about the dates and places of meetings. An important role is also played here by housing-estate councils. $25 \%$ of

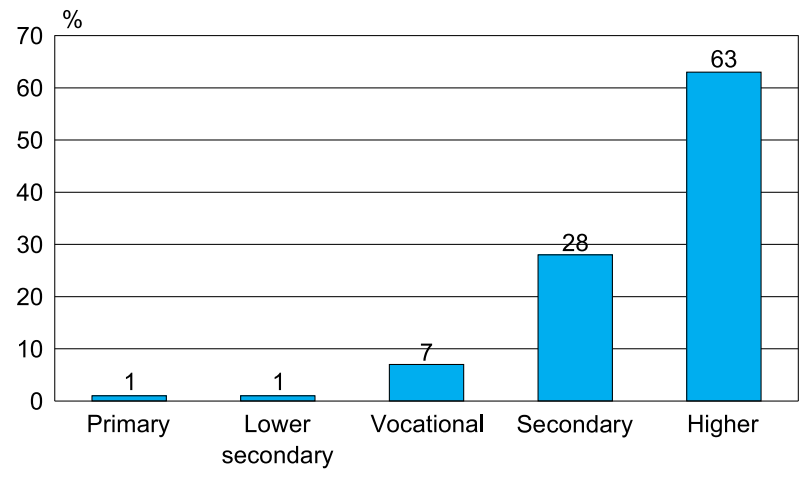

Fig. 4. Structure of consultation participants by education.

Source: own compilation.

participants are informed in writing by an appropriate council or in the form of posters and notices $(12 \%)$. The survey results show a dependence between the age of consultation participants and their source of information about a meeting. Persons over 50 learn about it much more often through an estate council, notices, posters, or from friends; younger people, up to 40, derive this information mostly from the Internet and local television.

The basic reason of Poznań residents for participating in public consultations on local plans is the nearness of their places of residence to the area covered by a plan or a property located in the area or nearby. $40 \%$ of the respondents participate in consultations because a future plan will directly affect their place of residence and real-estate property. In turn, 16\% declare themselves interested in spatial development matters in their district and in the city at large, and want to have a more detailed knowledge of what is

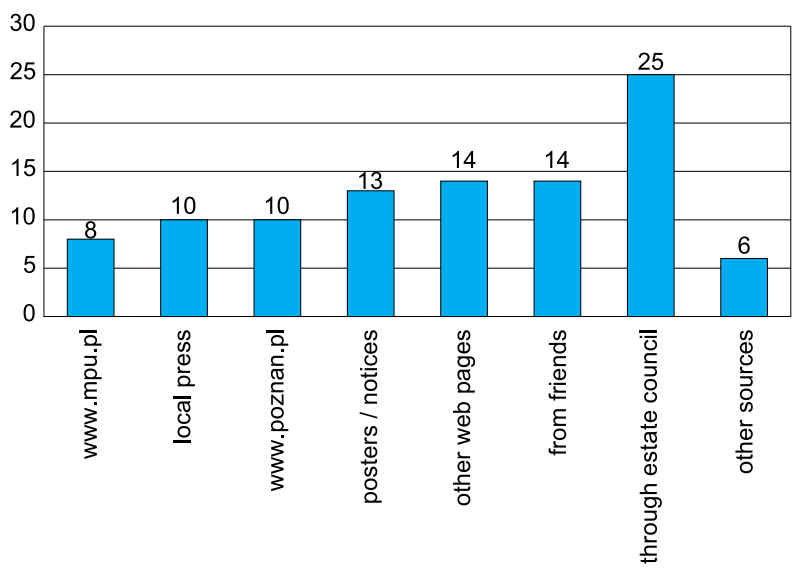

Fig. 5. Sources of information about public consultations.

Source: own compilation. 


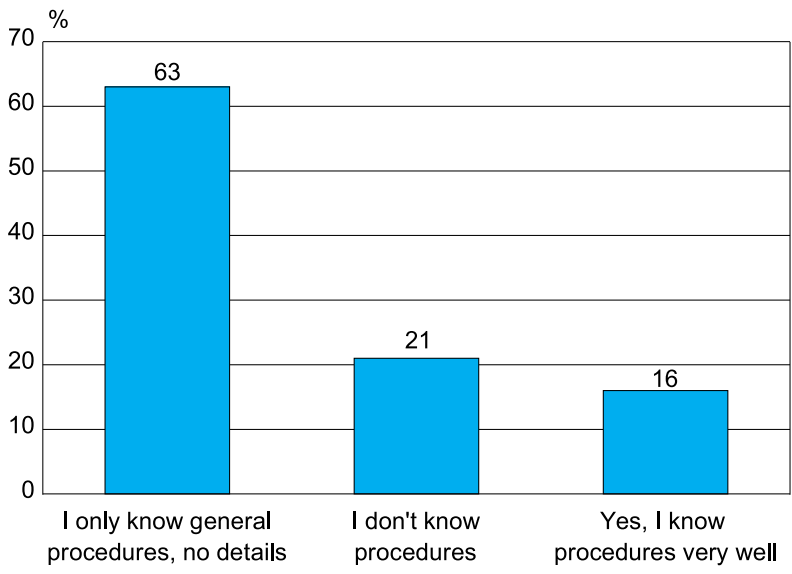

Fig. 6. Knowledge of public consultation participants about planning procedures.

Source: own compilation.

being planned. A significant group takes part in consultations because the area under discussion is a valuable element of the city, e.g. in the field of recreation and leisure (15\%). Also notable is a group of persons whose participation in meetings follows from their concern for the interests of local communities (13\%). The other reasons include: curiosity or no direct interest $(6 \%)$, activity in an estate council (4\%), an intention to invest in the area covered by the plan (4\%), and occupational work in this area.

A mere $16 \%$ of the respondents declare to have a very good knowledge of current procedures of preparing and passing local spatial development plans. A decided majority (62\%) have only a general, often imprecise knowledge of planning procedures. $21 \%$ declare no knowledge about planning questions.

The results of the survey research show the representation of city residents in the consultations to be limited. Clearly under-represented are those with education under secondary and young people, while those of the post-working age and persons with higher education are over-represented. This means it is necessary to think of additional methods that would involve all social groups in the consultations. Also unsatisfactory is consultation participants' planning knowledge, which makes it necessary to improve the system of informing and educating residents about the legal foundations and procedures of spatial planning.

\section{Strong and weak points of public participation in the planning process}

Poznań is an example of a city where the authorities have decided to extend the statutory procedures of public consultations about the local plans prepared. Since 2007 there have been additional consultations with residents not stipulated in the 2003 Planning Act. The Poznan model of such extra consultations results in the engagement of a decidedly larger number of persons interested in what a plan is about. This takes place at a much earlier stage in the planning procedure, which allows a successful elimination of emerging conflicts and finally makes the passing of the plan quicker. The consultative procedure implemented in Poznań is a platform for an exchange of opinions among various groups of stakeholders taking part in the spatial planning process in the city.

The strategy of increasing the number of consultative meetings in the process of preparing spatial development plans adopted by the city authorities and the planning service has produced several good results, the most important being: 1) improving the knowledge of city residents about general principles of spatial planning and spatial development, especially the rights and duties of individuals in the planning process, and about procedures involved in the passing of plans; 2) informing a local community living in the area concerned about the start of work on a local spatial development plan (stage 1 ) and presenting a draft plan (stage 2 ) in a place closest to where it lives; 3 ) reducing the mental and psychological distance between the City Office and residents and building mutual trust and good partnership relations as a plane of cooperation; 4) collecting opinions, comments and reservations from persons/institutions involved in the consultative process in order to work out a draft plan satisfying possibly the largest group of participants; 5) eliminating at an early stage of the procedure as many social/spatial conflicts as possible that can have an adverse effect on further planning work; 6) convincing meeting participants about the rationality of the specialised designing solutions introduced; 7) obtaining social acceptance of the draft plan at the earliest possible stage in the planning procedure, often 
before the statutory stage of its presentation for public inspection; and 8) shortening the time of passing a local plan, thus reducing the cost of its preparation.

The above benefits following from the extensive public consultation system when passing spatial development plans in the Poznan planning practice are certainly not fully satisfactory. The procedure of public consultations has disadvantages deriving from their formula. As follows from the survey research among their participants, involvement in consultations is rather weak. Readily visible at consultative meetings is the over-representation of older people (over 60), which is mostly due to the free time they have, and the under-representation of young ones (under 30). Various organisations take part in consultations on behalf of housing-estate residents and even citizens of the entire city, but often representing their own particular interests, not always fully coinciding with those of the community living in the area concerned. In the groups of stakeholders little activity is shown by representatives of economic entities.

\section{New public consultation methods with the use of the Internet}

One of the consultation instruments worth introducing is the Internet geographical information system, or public participation GIS, or participatory GIS (PPGIS). This is a modern consultation method involving the creation of a special Internet portal allowing a greater engagement of residents in consultations on a spatial development plan. Its deliberative functions would be ensured by the possibility of adding opinions and asking its authors questions. An interactive debate over a plan could involve marking existing or new objects on a map and linking them to the text of a comment. So far the proposed method has not been used in Polish towns. There are also no good international examples of the implementation of PPGIS into the spatial planning formal procedures.

As Jankowski (2009), Kahila and Kyttä (2010) and Kingston (2011) indicate, the use of PPGIS in public consultations on planning can enhance its transparency and raise its level of participation, and thus make the planning process more efficient. Its effect can be greater public trust and a better understanding of the urban policy by consultation participants. It also makes participation easier to social groups so far not represented in consultations, chiefly young people. In view of the accessibility of information technologies in various age groups and the phenomenon of digital exclusion, Internet consultations should be treated as a 'complementary form of consultations and conducted alongside traditional consultative meetings. It is worth noting, however, that, as the survey research has demonstrated, today it is the Internet that is the most common source of information about public consultations organised by the Poznań City Office. The use of modern public communication instruments can be expected to set trends in public participation in the spatial planning process in the very near future, especially in large cities.

In Poznań, the first attempt at using the GIS instrument to prepare a local spatial development plan took place in 2014 and concerned the development of the Kasprowicz Park area (Jankowski et al. 2015). It lies in the city's south-western part, on the border between the downtown districts of Łazarz and Grunwald. The area concerned mostly embraces Kasprowicz Park with its sporting and recreational facilities as well as some housing and green allotments.

Between 13 October and 17 November 2014 a study of residents' preferences concerning the future spatial development of Kasprowicz Park was conducted using the Internet spatial information system. The chief research tool was a geo-survey, or an Internet survey allowing respondents to locate a spatial type of information on a map (Jankowski et al. 2015). Its goal was to obtain information, mainly about individual preferences as to the future development of this area, that could help city planners to work out a plan. In the course of the research it was possible to acquire additional data, e.g. general characteristics of its participants, their places of residence, or ways of using the study area.

One of the goals of the research project was a comparison of the two parallel forms of public consultations on the Kasprowicz Park plan being prepared: a conventional consultative meeting (held on 20 Jan. 2014), which was a formal element of the planning procedure, and Internet consultations via the geo-survey. 


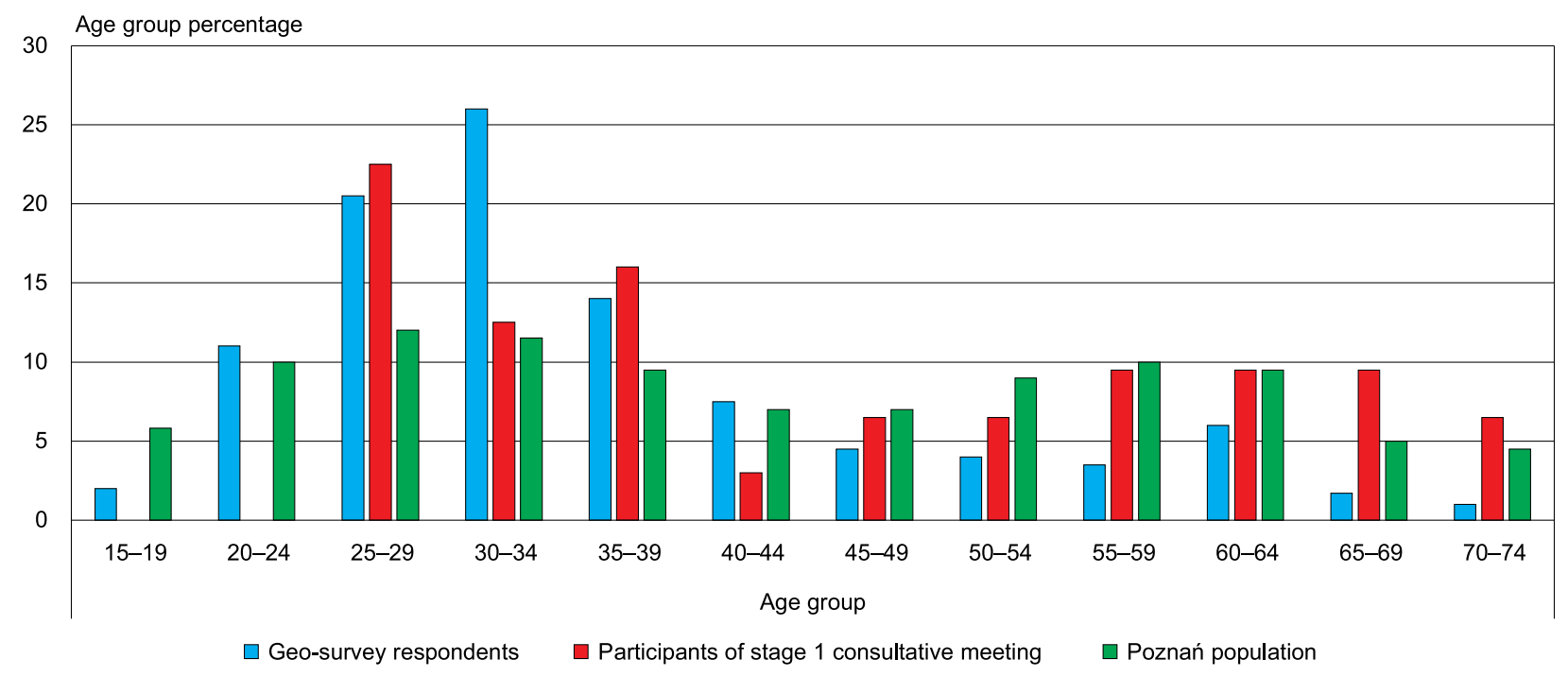

Fig. 7. Age structure of participants of traditional public consultations and Internet consultations. Source: own compilation on the basis of survey researches.

Among the participants of the traditional meeting, males made up $63 \%$ of their number, while in the Internet consultations they accounted for $52 \%$ (357 out of 683 persons who answered the question about sex). Unlike in the Internet study, well represented at the direct meeting were persons aged 55 and older, but there were no persons under 25, who, in turn, were active in the Internet study. This suggests that meetings and Internet methods are complementary in terms of the participation of the youngest and the oldest age groups.

The proportion of females up to 25 years old in the Internet consultations was almost twice as high as that of males in the same age group. In the case of the remaining age groups the difference between the number of females and males was similar. Participants of the Internet consultations were more diversified in terms of education than those taking part in direct meetings. In both cases there was a distinct predominance of people with higher education. On the Internet, also active, though to a decidedly lesser extent, were persons with secondary (19\%), vocational $(3.1 \%)$, primary $(1.3 \%)$ and other types of education $(2.2 \%)$. In traditional consultations, persons with secondary education constituted $10 \%$.

The most active occupational group engaged in both forms of public consultations about the LSDP for Kasprowicz Park in Poznań was employees of private firms. They accounted for $42 \%$ of participants of traditional consultations and $47 \%$ of those on the Internet. Clearly active in traditional consultations were freelancers $(21 \%)$, public administration workers $(17 \%)$, and pensioners $(13 \%)$, while students, pupils and non-working persons were absent. Those groups, in turn, engaged in Internet consultations, especially students $(12.6 \%)$.

\section{Summing up}

An effect of the liberalisation of spatial development in Poland has been the appearance of spatial conflicts in areas undergoing intensive urbanisation, especially in large cities. This is accompanied by an increase in the social awareness of and activity concerning the development of urban space. For more than 10 years now the spatial planning procedure has permitted public consultations when preparing local spatial development plans. However, they are not enough, and the conflicts mentioned above cannot be fully solved in this way. With Poznań as an example, an assessment was made of the present forms of public consultations and their effect on the processing of planning documents. The methods employed were participatory observation during public consultations and a survey research among their participants. Public activity was found to be low, with poor attendance at consultative meetings. The Internet tool used in Poznan in the form of a geo-survey, the first of this kind to be conducted in Poland, successfully eliminated the problem of the insufficient 
representativeness of traditional consultations. It is therefore necessary to improve the decision process in urban spatial planning by augmenting the traditional forms and instruments of public participation with new ones. They offer the possibility of greater participation and a wider social representation than the traditional consultative meetings.

\section{References}

Arnstein S., 2011. Drabina partycypacji (The participation ladder). In: Partycypacja. Przewodnik Krytyki Politycznej. Wydawnictwo Krytyki Politycznej, Warszawa.

Billert A., 2006. Planowanie przestrzenne a polityka. Trzecia droga do trzeciego świata (Physical planning and politics. A third way to the third world). In: Urbanistyka w działaniu. Teoria i praktyka. Materiały z II Kongresu Urbanistyki Polskiej, Biblioteka Urbanisty (9). Urbanista, Warszawa: $240-253$.

Długosz D., Wygański J.J., 2005. Obywatele decyduja. Przewodnik po partycypacji spotecznej (Citizens are decision-makers. A guide to public participation). Stowarzyszenie na rzecz Forum Inicjatyw Pozarządowych, Warszawa.

Fiedziukiewicz K., Udział społeczeństwa w planowaniu przestrzennym. Aspekty prawne (Public participation in physical planning. Legal aspects). Online: http://pspe. gridw.pl/?id=11 9 (accessed 20 June 2014).

Goździewicz-Biechońska J., 2008. Partycypacja społeczna $\mathrm{w}$ tworzeniu prawa na przykładzie miejscowego planu zagospodarowania przestrzennego (Public participation in law-making on the example of a local spatial development plan). Samorzad Terytorialny 7-8, Warszawa.

Harvey D., 2012. Rebel cities. From the right to the city to the urban revolution. Verso, London.

Hanzl M., 2008. Nowe możliwości udziału mieszkańców miasta w planowaniu przestrzennym jako wynik wykorzystania wspótczesnych technik komputerowych (New possibilities of participation of city residents in physical planning as a result of the use of modern computer techniques). Doctoral dissertation, Politechnika Łódzka, Łódź.

Hausner J., 1999. Komunikacja i partycypacja społeczna (Public communication and participation). Online: http:/ / www.wsap.edu.pl/pub/Biblioteka_@ntykorupcyjna/J.\%20Hausner\%20-\%20Komunikacja\%20i\%20partycypacja\%20spo\%B3eczna.pdf (accessed 20 June 2014).

Izdebski H., 2010. Nowe kierunki zarządzania publicznego a współczesne kierunki myśli politycznej (New directions in public management and contemporary directions in political thought). In: Bosiacki A., Izdebski H., Nelicki A., Zachariasz I. (eds), Nowe zarzadzanie publiczne w public governance w Polsce i w Europie. Warszawa.
Izdebski H., 2011. Samorzad terytorialny. Podstawy ustroju $i$ działalności (Territorial self-government. Foundations of the system and operation). Lexis Nexis, Warszawa.

Jankowski P., 2009. Towards participatory geographic information systems for community-based environmental decision making. Journal of Environmental Management 90: 1966-1971.

Jankowski P., Czepkiewicz M., Młodkowski M., Zwoliński Z., 2015. Geo-questionnaire: A method and tool for public preference elicitation in land use planning. Transactions in GIS.

Jaroszyński K., Sawicki M., 2004. Decyzje o warunkach zabudowy i zagospodarowania terenu (Decisions about the conditions of building and land development). Biblioteka Urbanisty 3, Warszawa.

Jędraszko A., 2008. Gospodarka przestrzenna w Polsce wobec standardów europejskich (Spatial management in Poland against European standards). Urbanista 13, Warszawa.

Kaczmarek T., 1993. Rola i formy uczestnictwa społeczności lokalnych $\mathrm{w}$ procesie zmian podziału terytorialnego (Role and forms of participation of local communities in the process of changes in the territorial division). Ruch Prawniczy, Ekonomiczny i Socjologiczny 3, Wydawnictwo Naukowe UAM, Poznań.

Kahila M., Kyttä M., 2010. SoftGIS as a bridge-builder in collaborative urban planning. In: Geertman S., Stillwell J. (eds), Planning support systems: Best practice and new methods. GeoJournal Library, Heidelberg.

Kingston R., 2011. On-line public participation GIS for spatial planning. In Nyerges T., Couclelis H., McMaster R. (eds), The SAGE handbook of GIS and society. SAGE Publications, London: 361-380.

Mergler L., Pobłocki K., Wudarski M., 2013. Anty-bezradnik przestrzenny: prawo do miasta $w$ dziataniu (Spatial anti-helplessness guide: the right to the city in action). Biblioteka Respubliki Nowej, Warszawa.

Parysek J.J., 2006. Wprowadzenie do gospodarki przestrzennej (Introduction to spatial management). Wydawnictwo Naukowe Uniwersytetu im. Adama Mickiewicza, Poznań.

Parysek J.J., 2010. Gospodarka przestrzenna i rola partycypacji społecznej $\mathrm{w}$ procesie planowania przestrzennego (Spatial management and the role of public participation in physical planning). In: Ratajczak W., Stachowiak K. (eds), Gospodarka przestrzenna społeczeństwu. Bogucki Wydawnictwo Naukowe, Poznań.

Wall T.D., Lischeron J.A., 1980. Zum Begriff der Partizipation. In: Participative Fuehrung. Betriebswirtschaftlische und Sozialpsychologische Aspekte. Verlag Paul Haupt, Bern und Stuttgart.

Ziemkiewicz K., 1990. Nauka o organizacji i zarzadzaniu (Science of organisation and management). PWN, WarszawaPoznań.

Ziółkowski M., 2005. Społeczeństwo obywatelskie, transformacja i tradycja we wspólnotach lokalnych (Citizen society, transformation and tradition in local communities). In: Bondyra K., Szczepański M.S., Śliwa P. (eds), Państwo, samorząd i społeczności lokalne. Wyższa Szkoła Bankowa, Poznań. 